$1-1-2015$

\title{
The Moderating Effect of Type of Deviance on the Relationships among Gender, Morality, Deviant Peers, and Deviance
}

Miyuki F. Tedor

Cleveland State University, m.fukushima@csuohio.edu

Follow this and additional works at: https://engagedscholarship.csuohio.edu/clcas_facpub

Part of the Gender and Sexuality Commons, and the Social Control, Law, Crime, and Deviance

Commons

How does access to this work benefit you? Let us know!

Publisher's Statement

This is an Accepted Manuscript version of the following article, accepted for publication in Deviant Behavior. Tedor, M.F. (2015). The moderating effect of type of deviance on the relationships among gender, morality, deviant peers, and deviance. Deviant Behavior, 36(3), $221-44,10.1080 / 01639625.2014 .924362$. It is deposited under the terms of the Creative Commons Attribution-NonCommercial License (http://creativecommons.org/licenses/by-nc/ 4.0/), which permits non-commercial re-use, distribution, and reproduction in any medium, provided the original work is properly cited.

\section{Recommended Citation}

Tedor, Miyuki F., "The Moderating Effect of Type of Deviance on the Relationships among Gender, Morality, Deviant Peers, and Deviance" (2015). Criminology, Anthropology, \& Sociology Faculty Publications. 6.

https://engagedscholarship.csuohio.edu/clcas_facpub/6

This Article is brought to you for free and open access by the Criminology, Anthropology, \& Sociology Department at EngagedScholarship@CSU. It has been accepted for inclusion in Criminology, Anthropology, \& Sociology Faculty Publications by an authorized administrator of EngagedScholarship@CSU. For more information, please contact library.es@csuohio.edu. 


\title{
The Moderating Effect of Type of Deviance on the Relationships among Gender, Morality, Deviant Peers, and Deviance
}

\author{
Miyuki Fukushima Tedor \\ Cleveland State University, Cleveland, Ohio, USA
}

\begin{abstract}
Empirical research indicates that males are not only more likely to associate with deviant friends, but are also more strongly affected by such association than females. Literature to date also finds that the gendered effect of deviant association is explained by the gender difference in morality, such that weaker morality leaves males more susceptible to the effect of deviant association. This study replicates previous research but goes further by utilizing unique self-reported data $(N=502)$ that contains 15 deviant behaviors and examines how the type of deviance moderates relationships among gender, morality, deviant association, and deviance.
\end{abstract}

Although gender is one of the most consistent and strongest correlates of deviance, this relationship has historically been ignored. Naffine (1996) posits that as the scientific approach became prominent in criminology, the object of inquiry became un-gendered so that the masculine nature of crime - the fact that males are more deviant than females - was left unexamined. Criminology's lack of attention to gender is paradoxical because it is gender's strong, persistent, and near-universal correlation with crime that makes this relationship an uninteresting fact. Within mainstream criminology, therefore, gender has either been ignored, when females are excluded, or treated with little theoretical significance, when females are added merely as a control variable in the analysis (Chesney-Lind 2006). Although there is a renewed interest in gender in recent years (e.g., Hagan, Gills, and Simpson 1985; Messerschmidt 1993; Zahn et al. 2010), Chesney-Lind (2006) contends that the lack of attention to gender within the mainstream criminological research continues (see also Sharp and Hefley 2007).

There are two dominant views on how to integrate gender into criminology research. Feminist scholars argue for more gender-focused theories of crime since causal factors might vary by gender (e.g., Belknap and Holsinger 2006; Bottcher 2001; Chesney-Lind 1989, 2006; Chesney-Lind and Pasko 2013: Daly 1994: Daly and Chesney-Lind 1988). This is undeniably an important theoretical extension to the field, but is beyond the scope of the current analysis. The Other approach contends that both genders share similar causal factors (Daigle, Cullen, and Wright 2007; Gottfredson and Hirschi 1990; Smith 1979; Smith and Paternoster 1987). This type of research 
generally applies extant theories of crime as an explanation for the gender gap in crime. From this perspective, theoretical variables purportedly affect: (1) the gender gap in criminality (through the gendered exposure to the theoretical variables and/or the gendered effect of the exposure to the theoretical variables); (2) the gender gap in opportunity to commit crime; or (3) both gender gaps in criminality and opportunity to commit crime (see Jensen 2003 for a review on this issue).

Of importance for this study is the first aspect: focusing on the gender difference in criminality as an explanation for the gender gap in criminal offending. Numerous empirical studies find that males are not only more exposed to criminogenic factors (gendered exposure) but also are more strongly affected by such exposure (gendered effect of the exposure), thereby explaining their higher overall deviance as compared to females. The patterns are found at the micro-level applying various theoretical variables (Alarid, Burton, and Cullen 2000; Broidy and Agnew 1997; Heimer and De Coster 1999; Mears, Ploeger, and Warr 1998; Morash 1986; Piquero et al. 2005) as well as at the macro-level (e.g., Steffensmeier 2000, who found that the structural criminogenic factors had stronger effects on male crime rates than on female crime rates; also see Steffensmeier and Haynie 2000). At the micro-level applying a variable from social learning theory, both Mears et al. (1998) and Piquero et al. (2005) found that in addition to males having more delinquent friends than females (gendered exposure), males' delinquency is more strongly affected by delinquent associations than females' delinquency (gendered effect of the exposure). The gendered effect of the exposure to delinquent friends was explained by the gender difference in morality in Mears et al. (1998) and morality and the perception of the certainty and severity of punishment in Piquero et al. (2005).

This study replicates these two studies but goes several steps further. First, although the two studies examined only a few deviant behaviors, this study utilizes unique self-report data that include a set of fifteen deviant behaviors to measure respondents' own and their perceptions of friends' deviance. The utilization of various deviant behaviors allows the study to take into account the different possible dimensions of deviance and the conditional effect that the type of deviance might have on the gendered effect of deviant association on one's own deviance. Second, this study also examines morality as a possible explanation for the gendered effect of association on deviance, replicating the previous two studies. Unlike specific measures of morality used in the two studies, however, this study utilizes general measures of morality that more appropriately capture social learning theory's conceptualization of morality - one based on respondents' views concerning rule breaking in general and the other based on respondents' religiosity.

\section{GENDER AND DEVIANCE}

There is a strong agreement across disciplines that one of the most consistent correlates in criminology is gender. The gender gap in crime is criminology's most trusted finding, true irrespective of the types of data and over time and space (Gottfredson and Hirschi 1990), and shown in numerous empirical studies (Heidensohn 2002: Hindelang 1979: Hindelang. Hirschi, and Weis 1979; Schwartz et al. 2009; Steffensmeier and Allan 1995, 1996; Steffensmeier, Allan, and Streifel 1989; Steffensmeier and Streifel 1991; Wilson and Hernstein 1985).

Women and men differ overall in terms of both rates and patterns of crime offending and victimization. Males commit crimes at higher rates than females (Gottfredson and Hirschi 1990; Steffensmeier et al. 1989). The size of the gender gap, however, is not constant but differs by 
the types of offense. Overall, the more serious, violent, and strongly condemned the behavior. the wider the gender gap in offending/victimization (Daly 1998; Steffensmeier and Allan 1996; Steffensmeier and Streifel 1991; Sutherland, Cressey, and Lukenbill 1992). This pattern is found using different types of data (Hindelang, Hirschi, and Weis 1981), across cultures and societies (Heidensohn 2002), and with deviant behaviors (Tittle and Paternoster 2000).

Although there are gender differences in terms of rates and patterns of crime, past studies nevertheless find considerable overlaps in the correlates of criminality across gender (e.g., Sheley 2000; Smith and Paternoster 1987; see Steffensmeier and Allan 1996 for a review). For instance, both male and female incarcerated populations are more likely to be racial/ethnic minorities, poor, and have a lower level of education (Chesney-Lind and Shelden 2004; Steffensmeier and Allan 1995). Additionally, the rates of crime often respond to the same structural forces over time and place for both genders (Steffensmeier 2000; Steffensmeier and Allan 1988; Steffensmeier et al. 1989), including the level of poverty, unemployment, and other characteristics of social disorganization (Steffensmeier and Haynie 2000).

The gender overlaps in criminality provide some legitimacy in applying the traditional theories of crime as explanations for female crimes, albeit most traditional theories are developed with male crime in mind. Indeed, empirical studies often find that traditional theories of crime are adequate in explaining crime and delinquency of females (Smith and Paternoster 1987; Steffensmeier and Allan 1995), such that theoretical variables explain females' engagement in crime equally as well as that of males', although they often fail to explain fully the gender gap in crime.

Other studies, however, have found that some theoretical variables have a gendered effect on deviance, such that these variables explain deviant behaviors of one gender more effectively than those of the other gender (e.g., Alarid et al. 2000; Heimer and De Coster 1999; Mears et al. 1998; Morash 1986; Piquero et al. 2005). The primary focus of this study is the purported gendered effect of an important theoretical variable from social learning theory, association with deviant peers, on deviance. Several empirical studies found that this social learning variable exerts significantly stronger effects on male deviance than on female deviance (Mears et al. 1998; Piquero et al. 2005).

\section{SOCIAL LEARNING THEORY AND GENDER}

Since Burgess and Akers' (1966) revisions to Sutherland's (1939) differential association theory, social learning theory has been considered one of the most important theories of crime (see Akers and Jensen 2008 for a review of the current state of this theory). At the center of this theory is the concept of "differential association," which refers to the interaction with others where learning of a certain behavior takes place. Empirical research consistently finds that association with delinquent peers is one of the best predictors of delinquency (Warr 2002).

What distinguishes social learning theory from other theoretical perspectives is its assumption that crime is learned. and learned through the process of social interaction. Because of its emphasis on social interaction, especially within an intimate group. Warr (2002) contends that social learning theory might be the key to explaining the gender gap in deviance. Empirical studies show some evidence to support this contention; for instance, a number of studies find that boys are more likely than girls to have delinquent friends (e.g.. Jensen 2003; Liu and Kaplan 1999; Morash 1986) or have friends who have a more favorable attitude toward delinquency 
(e.g., Simons, Miller, and Aigner 1980). These studies suggest that the gender gap in criminality might be due to males' higher exposure to a criminogenic factor, namely delinquent friends.

Furthermore, numerous studies found that males are not only more exposed to delinquent friends but also more strongly affected by such delinquent association than females. Johnson (1979), for instance, found that though association with delinquent peers was the most important variable predicting delinquency of both genders, the association had a stronger delinquencyinducing effect on male delinquency than female delinquency. This finding contradicts the belief that relationships are more important for females than males, as noted by Gilligan (1982), which would suggest a stronger peer influence on behaviors and beliefs of females than of males. Johnson's (1979) finding is not unique, however, as a number of subsequent empirical studies found similar results. Smith and Paternoster (1987), for instance, found that deviant peer association had a stronger influence on males' marijuana use than on females' marijuana use. Similarly, Daigle et al. (2007) and Lowe, May, and Elrod (2008) found that while the association with delinquent peers increased delinquency of boys, it did not affect delinquency of girls. These studies, therefore, suggest that the gender gap in criminality might also be explained by the gendered effect of the exposure to a criminogenic factor like association with delinquent friends. such that male criminality is more susceptible to the detrimental effect of such association than female criminality.

It should be noted, however, that not all empirical studies found a stronger effect of exposure to delinquent friends on male delinquency compared to female delinquency. For instance, a study conducted in rural France by Hartjen and Priyadarsini (2003) found that although the association with delinquent peers had a significant positive effect on delinquency of both genders, there was no gender difference in the strength of the effect of such delinquent association. Using the data collected among a nationally representative sample of young adults in the United States, Preston (2006) found a stronger effect of peers' drug use on females' drug use compared to males 'drug use. Zimmerman and Messner (2010) also found a stronger effect of exposure to friends' violent behaviors on females' violent offending than males'. Finally, using data from the Netherlands, Weerman and Hoeve (2012) found that the effect of peers on delinquency was similar for girls and boys, although the characteristics of delinquent association vary by gender. The review of exact research indicates that it is premature at this point to draw a conclusion regarding the gendered effect of deviant association because of a lack of systematic replications of the empirical test of the issue, also noted by Piquero et al. (2005). In addition to the systematic replications, moreover, the review of literature also indicates that further research is needed that identifies factors that would explain the mixed results. Therefore, one of the main objectives of this study is to examine one possible factor, the type of deviant behaviors, and how it might moderate the gendered effect of association on deviance.

Furthermore, additional research is needed that examines the process of the gendered effect of the exposure to delinquent peers. Indeed the review of literature found only two empirical studies that went beyond a mere examination of the gendered effect of association to offer an explanation why such gendered effect might exist. Mears et al. (1998) applied Gilligan's (1982) theory of gendered moral development and found that females' stronger moral orientation against delinquency inhibited delinquency, making females less susceptible to the effect of the delinquent association. Piquero et al. (2005) applied internal and external constraints (i.e., moral beliefs and severity and certainty of legal sanctions). Somewhat contrary to Mears et al. (1998), Piquero et al. (2005) found that the gendered effect of association with delinquent friends varies depending 
on the levels of internal and external constraints and the moderating effect of morality on the relationship between delinquent association and delinquency is similar across gender. Another objective of this study is to replicate the two studies and examine morality as an explanation for the gendered effect of deviant association on deviance. This study, however, utilizes general measures of morality that more appropriately capture social learning theory's conceptualization of morality than those used in the previous two studies.

\section{CURRENT STUDY}

It is both paradoxical and unfortunate that the lack of attention to gender within the mainstream criminological research continues because as one of the most consistent and strongest correlates of crime, gender might be a key to understanding crime and delinquency. This study contributes to the gender-focused empirical research in criminology through an examination of the gendered effect of the exposure to one of the most popular theoretical variables in criminology, delinquent association. While some studies found a gendered effect of the exposure to delinquent association. such that males are significantly more susceptible to the effect of delinquent association compared to females, only two empirical studies went beyond merely establishing the gendered effect to provide an explanation why such gendered effect might exist. This study replicates the studies by Piquero et al. (2005) and Mears et al. (1998) but goes several steps further.

First, though studies consistently find that the gender gap varies depending on the type of deviance, the two studies examined only one or two deviant behaviors (e.g.. vandalism and minor theft in Piquero et al. 2005 and minor theft in Mears et al. 1998). It is possible that the gendered effect of the association with deviant peers exists only for some types of deviance and that no such gendered effect exists for other types of deviance, thus providing an explanation for the mixed results across studies. This study takes into account the possible dimensionality of deviance using fifteen different types of deviant behaviors and corresponding deviant association measures and examines whether the gendered effect of association with deviant peers exists in any type or only in some types of deviant behaviors.

Studies from developmental psychology provide support to the importance of taking into account the dimensionality of deviance, especially when examined across gender. Consistent with Gilligan's (1982) argument that boys are socialized to be more competitive and to foster instrumental goals while girls are socialized to foster expressive and relational goals, Crick and Grotpeter (1995), for instance, found that upon encountering similar relationship problems, boys tend to resort to more overt and physical forms of aggression toward others (e.g.. punching) and girls tend to resort to more covert and relational forms of aggression toward others (e.g., spreading negative rumors). Furthermore, Crick, Bigbee, and Howes (1996) found that children in their study perceived covert relational aggression as equally harmful as overt aggression. The studies by Crick and her colleagues, therefore, indicate that upon experiencing a similar situational inducer, males and females react and express their aggression through different deviant behaviors.

Among major theories of deviance, Agnew's general strain theory (GST) in particular emphasizes the dimensionality of deviance and the possibility that theoretical variables might have varying effects on deviance, depending on the type of deviant behaviors. According to Agnew (2006:194), a specific strain might lead to a specific type of deviance, rather than a general strain leading to a general deviance, since "different strains may lead to different emotions, and different 
emotions may be conducive to different types of crime." Applying this idea further to the relationship between gender and deviance, Broidy and Agnew (1997) posit that not only might females and males experience different types of strains, they might also experience different emotional responses to the same strain that would result in different types of deviant behaviors, as was found in the studies by Crick and her colleagues. In support of their argument, while examining two types of deviant behaviors (general delinquency, which is more common among males, and eating disorders, which is more common among females), Sharp, Brewster, and Love (2005) found that males and females differed in how negative emotions that result from a certain strain led to these two types of deviant behaviors. In other words, there was a gendered effect of strain on deviance, much like the gendered effect of the association with delinquent peers on delinquency, but it varied depending on the type of deviant behaviors.

Past studies consistently find that males and females exhibit their criminality differently through engagement in different types of deviant behaviors. Ignoring this gender difference and examining only a few deviant behaviors that are more prevalent among males, like the previous two studies, might prevent us from understanding fully the relationship between gender and deviance. Males and females might engage in different types of deviant behaviors because of the gender difference in deviant association, such that corresponding variations in the gender gap in deviant association may exist depending on the type of deviant behaviors. For instance, the larger gender difference in serious deviance may be explained by a correspondingly larger gender difference in serious deviance association, while the smaller gender difference in minor deviance may be explained by a correspondingly smaller gender difference in minor deviance association. Furthermore, the variation in the gender gap in deviance across types of deviant behavior may also be explained by the gender difference in the effect of deviant association across different types of deviance. For instance, the effect of serious deviance association may be weaker on female deviance compared to male deviance, as some studies found. while the effect of minor deviance association may be the same for the deviance of both genders. In other words. the expected gendered effect of deviant association might not be consistent but vary depending on the type of deviant behaviors examined, as noted by GST and the studies by Crick and her colleagues. The mixed results revealed with the literature review that tested social learning theory as an explanation of the gender gap in deviance or the gendered effect of its theoretical variables might, therefore, be due to variations in the type of deviant behaviors these studies examined. Taking this into account, this study considers the possible dimensionality of deviance and examines how such dimensionality might moderate the expected gendered effect of deviant peers on deviance.

Second. previous studies created morality measures that are specific to the deviant behaviors they examined: Piquero et al. (2005:259) asked the question "How wrong do you think it is for someone to [act]?" and Mears et al. (1998:255) asked the question "How wrong do you think it is for someone your age to [act]?" In both studies, the "act" refers to the specific delinquent act used to measure respondents' own delinquency involvement (e.g., vandalism and minor theft for Piquero et al. and minor theft for Mears et al.). These specific morality measures are essentially the measures of the theoretical concept, "the specific definition," in Akers' social learning theory (Akers and Sellers 2012:83). This is potentially problematic for social learning theory given its premise that it is the differential association that affects specific definitions, rather than the other way around.

On the other hand. this study utilizes general measures of morality that more appropriately capture social learning theory's conceptualization of morality or "the general definition" (Akers 
and Sellers 2012:83). Morality conceptualized generally in this study is an enduring individual characteristic that is developed over time and can affect not only with whom one interacts but also "specific definitions" or one's views toward specific deviant behaviors. Unlike the specific morality measures used in the previous two studies, therefore, our general morality measures would not contradict social learning theory's premise regarding the effects among association, definitions, and subsequent deviance. For this study, one general morality measure was created based on respondents' levels of agreement with five statements concerning rule breaking in general, including for instance "it is alright to get around the law when you can get away with it" (see Table 1 for a complete list of statements). This study also includes a measure of religiosity, which Akers and Sellers (2012:83) consider as also a kind of "the general definition" along with morality, and was created based on respondents' frequency of participating in religious activities.

As previous studies noted, the gender difference in morality may play an important role in explaining the gendered effect of association on deviance. Empirical research supports Gillligan's (1982) argument concerning the gender difference in moral development; for instance, Beutel and Marini (1995) found that females, as compared to males, are more likely to show concern for others' well being, be less concerned with material benefits, and consider finding importance in the meaning of life important. The last point is especially pertinent to explaining the gender difference in religiosity. Past research finds that females are more likely to consider religion to be an important part of their lives, be more committed to religion, and be more likely to participate in religious activities than males (e.g., Batson and Ventis 1982; Bensen, Donahue, and Erickson 1989; Caplow, Bahr, and Chadwick 1983; Cornwall 1989; Stark and Bainbridge 1985).

Furthermore, general morality measures used in this study might explain the difference in the gendered effect of deviant association across the type of deviance. If the strength of the effect of deviant association varies depending on the type of deviance, then such gender difference might be explained by the gender difference in morality. For example, deviant association might not increase serious deviance but increase minor deviance for females, while it increases both types of deviance for males. In other words, stronger morality of females could prevent the effect of deviant association only on more serious deviance but not on less serious deviance. Indeed, past studies that examined religiosity's effect on deviance suggest that its preventive effect against deviance varies depending on the type of deviance. For instance, Burkett and White (1974) found that religiosity plays a much more important role in preventing behaviors that concern pleasure and that are less strongly condemned (e.g.. drinking and sex) than behaviors that are morally unambiguous and more strongly condemned by society (e.g., murder and rape). Similarly, morality's preventive effect against deviant association might vary depending on the type of deviance. Using these two general morality measures that more appropriately capture social learning theory's conceptualization of morality or "the general definition," this study replicates the studies by Piquero et al. (2005) and Mears et al. (1998). This study examines specifically how the gender difference in morality could explain the expected gendered effect of deviant association, while taking into account the moderating effect of the dimensionality of deviance.

\section{DATA AND MEASURES}

Data for this study are based on a self-reported survey of 504 undergraduate students enrolled in a major state university in the Southwest with a student population of around 22,000. The mean 
TABLE 1

Percentages and Factor Loadings of Deviance and Morality Items

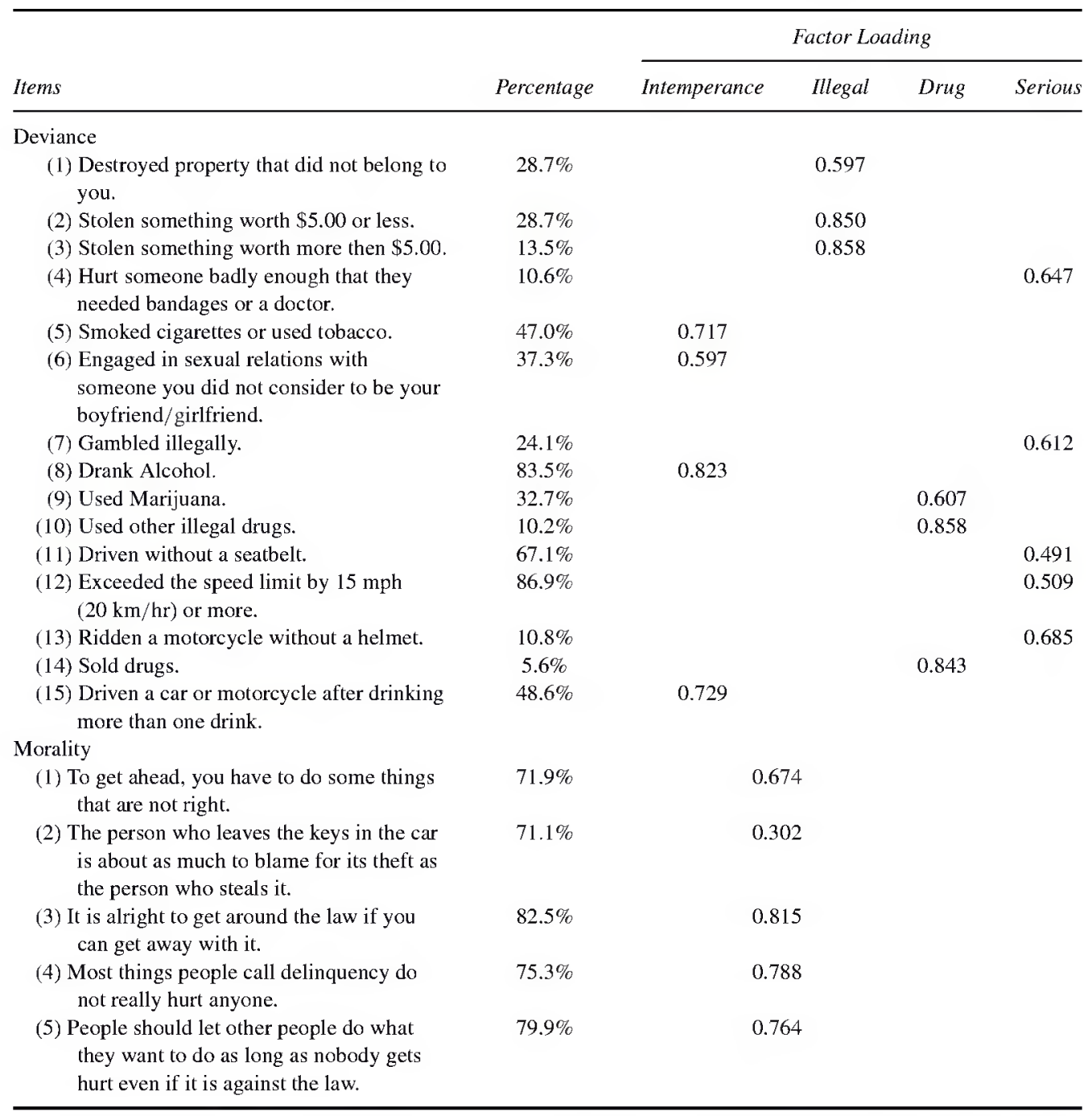

For deviant behaviors, the percentage refers to the percentage of those who have ever engaged in the deviant behaviors (including those who "rarely," "sometimes," "often," and "almost always" engaged in the behaviors. For morality, the percentage refers to the percentage of those who "strongly disagree" or "disagree" with the statements.

age of the sample is 19.68 and $91 \%$ are twenty-one years old or younger. Although this sample is non-random, it does correspond to the university population in the distribution of race and ethnicity with $74 \%$ being whites but not for gender. While $57 \%$ of the respondents in the survey are female, only $49 \%$ of the university student population at the time of survey administration was female, although data provided by the provost of the university indicate that the incoming 
freshman class for the year the survey was administered was $52 \%$ female. After eliminating two cases with missing gender, the analyses were conducted on the data from 502 respondents. All other missing cases were imputed with either the mean or the mode calculated separately for the corresponding gender.

\section{Control Variables}

Besides gender (males $=1$ ), the analyses controlled for three socio-demographic variables measuring age, race, and SES. The distribution of age was positively skewed $(s . k .=2.97)$, thus five students older than 25 were recoded to 25 , and this variable was treated as an interval-ratio variable. Race is a dummy variable, where whites were coded 1 and all others were coded 0 . Finally, SES is a dummy variable based on parents' highest educational levels, wherein respondents who had at least one parent with a college degree or higher were coded 1 (61.8\% of the respondents).

\section{Deviance}

Regarding fifteen deviant behaviors, respondents were asked, "How often have you engaged in the behavior in the past year?" Answer choices ranged from "never" $(=0)$ to "almost always" (=4). Table 1 shows a list of fifteen deviant behaviors along with the percentage of those who have ever engaged in each of the fifteen behaviors. A factor analysis of the fifteen deviant behaviors indicated four factors (see Table 1 for the factor loadings based on Varimax rotation). Reliability analysis showed that the reliability of the four factors were moderate (alphas $=0.792$, $0.760,0.805$, and 0.639 , respectively). Four deviance scales were created by summing the zscore transformations of items loading on each of the four factors. Although these four scales do not necessarily show four clear deviance groups, based on a general characteristic shared by most of the items loading to each factors, the four scales were named intemperance deviance $(S D=3.14)$, illegal deviance $(S D=2.47)$, drug deviance $(S D=2.54)$, and serious deviance $(S D=3.20)$, respectively. These scale names were chosen for the ease of interpreting the results, and thus, there are conceptual overlaps of behaviors across scales (e.g., "exceeding speed limit"), which is a component of serious deviance, is an illegal behavior.

\section{Deviant Association}

The variables measuring association with deviant friends were created based on respondents' answers to the question "In your opinion, how many of your close friends engaged in the behavior in the past year?" The question was asked regarding each of the identical fifteen deviant behaviors as those asked about the respondent. Response choices ranged from "none of them" $(=0)$ to "almost all of them" $(=3)$. The factor analysis of the fifteen deviant association items produced factors that differed slightly from those for deviance. I decided to create four deviant association scales that matched the four deviance scales to allow an interpretation of results in a theoretically meaningful way and to examine whether a theoretical scale matching a deviance scale explains the deviant behavior more effectively than do un-matching theoretical scales. Four deviant association scales were created by summing the $z$-score transformations of items 
matching those for respondents' own deviance scales and heretofore called intemperance association $(S D=3.22)$, illegal association $(S D=2.60)$, drug association $(S D=2.55)$, and serious association $(S D=3.44)$.

\section{Morality}

Two variables measuring morality were created for this study. The first morality measure was created based on respondents' views on five statements regarding breaking laws. The answer categories ranged from "strongly agree" $(=0)$ to "strongly disagree" $(=3)$, and each item was coded so that a higher value indicated stronger moral beliefs. Table 1 shows a list of five morality statements along with the percentage of those who indicated either "strongly disagree" or "disagree" to each of the five statements. The factor analysis of the five morality items indicated a single factor solution (see Table 1 for the factor loadings based on Varimax rotation) with an alpha of 0.711 . The second item on the list was, however, removed from the morality scale since the alpha was increased by 0.057 . A morality scale was created by summing the $z$-score transformations of the four remaining items. The second morality measure, religiosity, is an ordinal variable measuring respondents' frequency of participating in religious activities, ranging from "never" $(=0)$ to "more than one time per week" $(=4)$. Overall, $21.3 \%$ of the respondents indicated that they never participate in religious activities, and about $37 \%$ indicated that they attend religious activities at least once a week.

\section{ANALYSIS RESULTS}

Rather than four separate General Linear Model (GLM) models (one for each of four deviance scales), a Multivariate General Linear Model (MGLM) was used for this study because dependent variables were significantly correlated with each other. Findings from separate GLM models may be redundant and correlation would make it difficult to separate out the individual effects. Using MGLM, the correlations among dependent variables are accounted for, and relationships between independent and dependent variables can be separated. Another reason why MGLM is preferred over GLM in this study is that MGLM controls the family-wise error rates, or the increased odds of finding an independent variable significant because of the repeated use of the same sample of data. In this study, multivariate normality can be assumed due to the normality assumption being valid for each of the independent variables, and all multivariate and univariate models discussed in this study were significant at the 0.05 significance level. Additionally, though tables do not show full equations, all analyses were fully specified with controls for age, race, and SES. Finally, all models were reanalyzed using separate GLM models with collinearity diagnostics to test for a multicollinearity because SPSS does not run collinearity diagnostics for MGLM. All models reported were with variables that had variance inflation factors (VIFs) of less than 4.0, which is less than the rule of thumb commonly used (O'Brien 2007). In fact, most models had variables with VIFs less than 2.5, lower the standard discussed in Allison (1999). The inclusion of all four association scales at once or two morality measures at once, moreover, did not produce VIFs greater than 2.5 . The only models with VIFs above 2.5 were those with interaction terms (see Tables 3 and 4), and nevertheless, most interaction terms and their direct measures had variables with VIFs less than 3.5 . 
In the following. I report the analyses conducted across four types of deviance on: (1) the gender gap in deviance; (2) the gender gap in deviance explained through (a) the gendered exposure to deviant association and (b) the gendered effect of the exposure to deviant association; and. finally, (3) the gender difference in how morality moderates the effect of exposure to deviant association on deviance.

\section{Gender Gap in Deviance and Deviant Association}

I first examined the gender gap in deviance by regressing deviance on gender and three control variables (see the model for deviance in Table 2). The results indicate that males are significantly more deviant than females for all four types of deviance. Consistent with the past research. moreover, the gender gap is wider in more strongly condemned deviance (illegal and serious deviance) than in less strongly condemned deviance (intemperance and drug deviance). Next, I examined the gender gap in deviant association by regressing deviant association on gender and three control variables (see the model for deviant association in Table 2). The results for deviant association look identical to those for deviance, with males being significantly more exposed to deviant peers who engage in all four types of deviance. Once again, the gender gap is wider in illegal and serious association than in intemperance and drug association.

\section{Gender Gap in Deviance Explained by Deviant Association}

The similarity between deviance and deviant association in terms of how gender relates to them overall led to a prediction that the gender variation in deviant association can account for the

TABLE 2

Multivariate General Linear Model Regressing Deviance and Deviant Association on Gender and Three Control Variables, $N=502$

\begin{tabular}{|c|c|c|c|c|c|c|c|c|}
\hline \multirow[b]{2}{*}{ Type of deviance } & \multicolumn{4}{|c|}{ Deviance } & \multicolumn{4}{|c|}{ Deviant association } \\
\hline & $B$ & $p$ & $S E$ & $t$ & $B$ & $p$ & $S E$ & $t$ \\
\hline \multicolumn{9}{|l|}{ Intemperance } \\
\hline Intercept & -6.394 & $* *$ & 2.002 & -3.193 & -1.520 & & 2.084 & -0.729 \\
\hline Gender $($ Males $=1)$ & 1.101 & $* * *$ & 0.279 & 3.947 & 0.974 & $* *$ & 0.290 & 3.357 \\
\hline Adj. $R^{2}$ & 0.052 & & & & 0.024 & & & \\
\hline \multicolumn{9}{|l|}{ Illegal } \\
\hline Intercept & -0.837 & & 1.535 & -0.546 & 1.888 & & 1.599 & 1.181 \\
\hline Gender (Males = 1) & 1.614 & $* * *$ & 0.213 & 7.568 & 1.832 & $* * *$ & 0.223 & 8.224 \\
\hline Adj. $R^{2}$ & 0.100 & & & & 0.115 & & & \\
\hline \multicolumn{9}{|l|}{ Drug } \\
\hline Intercept & -6.984 & $* * *$ & 1.622 & -4.306 & -0.764 & & 1.652 & -0.462 \\
\hline Gender $($ Males $=1)$ & 0.728 & $* *$ & 0.226 & 3.223 & 0.904 & $* * *$ & 0.230 & 3.930 \\
\hline Adj. $R^{2}$ & 0.053 & & & & 0.024 & & & \\
\hline \multicolumn{9}{|l|}{ Serious } \\
\hline Intercept & -5.592 & $* *$ & 1.906 & -2.934 & -3.858 & & 2.123 & -1.817 \\
\hline Gender $($ Males $=1)$ & 2.437 & $* * *$ & 0.265 & 9.180 & 2.191 & $* * *$ & 0.296 & 7.409 \\
\hline Adj. $R^{2}$ & 0.172 & & & & 0.109 & & & \\
\hline
\end{tabular}

${ }^{*} p<.05:{ }^{* *} p<.01:{ }^{* * *} p<.001$. All significance tests are two-tailed tests. All models include controls for age, SES, and race. 
gender variation in deviance. To examine this, four association scales were added all at once to the model with deviance regressed on gender and three control variables (see Model 1 for the combined sample in Table 3). The results indicated that deviant association explains more effectively the gender gap in less strongly condemned deviance (intemperance and drug deviance) than in more strongly condemned deviance (illegal and serious deviance), as the effect of gender was reduced significantly in the former two equations while gender remained significant and strong on the latter two equations. In fact, drug association explained away the gender gap in drug deviance.

Furthermore, our results in Table 3 overall provide some support to the contention that the matching theoretical variable has a stronger effect on deviance than do un-matching theoretical variables. In other words, though any deviant association measures would capture an individual's overall level of association with deviant friends, an individual's engagement in drug deviance, for instance, is affected more strongly by his/her association with peers who engage in drug deviance than in other types of deviant behaviors. I found that the matching deviant association scale not only had the strongest effect but was the only association scale significant in explaining deviance, except for the significant effects of drug and serious association on intemperance deviance.

\section{The Gendered Effect of Deviant Association}

The gendered effect of deviant association was examined next by entering an interaction term between gender and each of the deviant association measures that were significant in the previous model (see Model 2 for the combined sample in Table 3). To interpret easily the significant interaction effects, Table 3 also shows the model separated by gender. Overall, I found that there was a gendered effect of deviant association on intemperance, drug, and serious deviance but not on illegal deviance. Results overall indicate that deviant association does not always exert a significantly stronger effect on male deviance than female deviance, and the direction of the gendered effect varies depending on the type of deviance, offering a possible explanation why past studies found inconsistent results with regard to the gendered effect of association on deviance.

Model 3 shows that while intemperance association had a significant positive effect for both genders, there was no significant gender difference in the strength of the effect of this association on intemperance deviance. In addition to the significant effect of intemperance association, females also experienced a significant positive effect of drug association and a significant negative effect of serious association on intemperance deviance, resulting in the significance of the interaction terms between gender and drug association and between gender and serious association on intemperance deviance. The aberrant effects of drug and serious association on intemperance deviance found in Model 1, therefore, were solely due to these associations' significant effects among females.

Model 3 shows that the only association measures with the expected gendered effect of deviant association were drug and serious association, thereby confirming past studies. While both drug and serious association had a significant positive effect on drug and serious deviance, respectively, for both genders, the effect of these association measures were felt significantly more strongly among males than females. The results presented in Table 3 overall support our contention that the gendered effect of deviant association may vary depending on the type of deviance. 
TABLE 3

Multivariate General Linear Model Regressing Deviance on Gender, Three Control Variables1, Deviant Association, and Interaction Terms Between Gender and Each of the Deviant Association Scales for the Combined Sample and Males and Females Separately

\begin{tabular}{|c|c|c|c|c|c|c|c|c|c|c|c|c|c|c|c|c|}
\hline \multirow[b]{3}{*}{ Type of deviance } & \multicolumn{8}{|c|}{$\begin{array}{l}\text { Combined } \\
(N=502)\end{array}$} & \multirow{2}{*}{\multicolumn{4}{|c|}{$\begin{array}{c}\text { Males } \\
(n=214)\end{array}$}} & \multirow{2}{*}{\multicolumn{4}{|c|}{$\begin{array}{c}\text { Females } \\
(n=288)\end{array}$}} \\
\hline & \multicolumn{4}{|c|}{ Model I } & \multicolumn{4}{|c|}{ Model 2} & & & & & & & & \\
\hline & $B$ & $p$ & $S E$ & $t$ & $B$ & $p$ & $S E$ & $t$ & $B$ & $p$ & $S E$ & $t$ & $B$ & $p$ & $S E$ & $t$ \\
\hline \multicolumn{17}{|l|}{ Intemperance } \\
\hline Intercept & -5.817 & $* * *$ & 1.497 & -3.885 & -5.596 & $* * *$ & 1.468 & -3.812 & -4.565 & & 2.547 & -1.792 & -5.439 & $* *$ & 1.712 & -3.177 \\
\hline Intemperance Association & 0.587 & $* * *$ & 0.045 & 12.904 & 0.573 & $* * *$ & 0.045 & 12.764 & 0.579 & $* * *$ & 0.078 & 7.408 & 0.571 & $* * *$ & 0.052 & 11.074 \\
\hline Illegal Association & 0.055 & & 0.053 & 1.036 & & & & & & & & & & & & \\
\hline Drug Association & 0.160 & $* *$ & 0.054 & 2.940 & 0.340 & $* * *$ & 0.071 & 4.785 & 0.037 & & 0.082 & 0.456 & 0.348 & $* * *$ & 0.066 & 5.276 \\
\hline Serious Association & -0.087 & $*$ & 0.041 & -2.012 & -0.195 & $* * *$ & 0.054 & -3.643 & 0.034 & & 0.062 & 0.545 & -0.197 & $* * *$ & 0.047 & -4.164 \\
\hline Gender $\times$ Drug Association & & & & & -0.299 & $* *$ & 0.090 & -3.339 & & & & & & & & \\
\hline Gender $\times$ Serious Association & & & & & 0.234 & $* *$ & 0.070 & 3.350 & & & & & & & & \\
\hline Adj. $R^{2}$ & 0.481 & & & & 0.494 & & & & 0.414 & & & & 0.552 & & & \\
\hline \multicolumn{17}{|l|}{ Illegal } \\
\hline Intercept & -1.945 & & 1.366 & -1.424 & & & & & & & & & & & & \\
\hline Intemperance Association & 0.044 & & 0.041 & 1.054 & & & & & & & & & & & & \\
\hline Illegal Association & 0.474 & $* * *$ & 0.048 & 9.808 & & & & & & & & & & & & \\
\hline Drug Association & 0.004 & & 0.050 & 0.088 & & & & & & & & & & & & \\
\hline Serious Association & -0.074 & & 0.038 & -1.959 & & & & & & & & & & & & \\
\hline Adj. $R^{2}$ & 0.298 & & & & & & & & & & & & & & & \\
\hline \multicolumn{17}{|l|}{ Drug } \\
\hline Intercept & -6.970 & $* * *$ & 1.303 & -5.348 & -6.568 & $* * *$ & 1.282 & -5.124 & -9.779 & $* * *$ & 2.333 & -4.192 & -3.605 & $*$ & 1.402 & -2.571 \\
\hline Gender $($ Males $=1)$ & 0.180 & & 0.194 & 0.925 & 0.177 & & 0.181 & 0.975 & & & & & & & & \\
\hline Intemperance Association & -0.029 & & 0.040 & -0.720 & & & & & & & & & & & & \\
\hline Illegal Association & 0.088 & & 0.046 & 1.917 & & & & & & & & & & & & \\
\hline Drug Association & 0.610 & $* * *$ & 0.047 & 12.875 & 0.479 & $* * *$ & 0.049 & 9.753 & 0.702 & $* * *$ & 0.059 & 11.870 & 0.479 & $* * *$ & 0.040 & 12.052 \\
\hline Serious Association & -0.063 & & 0.036 & -1.750 & & & & & & & & & & & & \\
\hline Gender $\times$ Drug Association & & & & & 0.227 & $* *$ & 0.070 & 3.266 & & & & & & & & \\
\hline Adj. $R^{2}$ & 0.401 & & & & 0.408 & & & & 0.429 & & & & 0.343 & & & \\
\hline
\end{tabular}


TABLE 3

(Continued)

\begin{tabular}{|c|c|c|c|c|c|c|c|c|c|c|c|c|c|c|c|c|}
\hline \multirow[b]{3}{*}{ Type of deviance } & \multicolumn{8}{|c|}{$\begin{array}{l}\text { Combined } \\
(N=502)\end{array}$} & \multirow{2}{*}{\multicolumn{4}{|c|}{$\begin{array}{c}\text { Males } \\
(n=214)\end{array}$}} & \multirow{2}{*}{\multicolumn{4}{|c|}{$\begin{array}{c}\text { Females } \\
(n=288)\end{array}$}} \\
\hline & \multirow[b]{2}{*}{$B$} & \multicolumn{3}{|c|}{ Model 1} & \multicolumn{4}{|c|}{ Model 2} & & & & & & & & \\
\hline & & $p$ & $S E$ & $t$ & $B$ & $p$ & $S E$ & $t$ & $B$ & $p$ & $S E$ & $t$ & $B$ & $p$ & $S E$ & $t$ \\
\hline \multicolumn{17}{|l|}{ Serious } \\
\hline Intercept & -3.968 & $*$ & 1.580 & -2.512 & -3.627 & $*$ & 1.549 & -2.342 & -3.770 & & 2.942 & -1.282 & -2.732 & & 1.568 & -1.742 \\
\hline Gender $($ Males $=1$ ) & 1.221 & $* * *$ & 0.236 & 5.180 & 1.303 & $* * *$ & 0.227 & 5.754 & & & & & & & & \\
\hline Intemperance Association & 0.011 & & 0.048 & 0.238 & & & & & & & & & & & & \\
\hline Illegal Association & 0.105 & & 0.056 & 1.883 & & & & & & & & & & & & \\
\hline Drug Association & -0.028 & & 0.057 & -0.483 & & & & & & & & & & & & \\
\hline Serious Association & 0.473 & $* * *$ & 0.043 & 10.903 & 0.374 & $* * *$ & 0.049 & 7.659 & 0.617 & $* * *$ & 0.056 & 11.103 & 0.375 & $* * *$ & 0.037 & 10.251 \\
\hline Gender $\times$ Serious Association & & & & & 0.252 & $* * *$ & 0.065 & 3.857 & & & & & & & & \\
\hline Adj. $R^{2}$ & 0.443 & & & & 0.457 & & & & 0.403 & & & & 0.266 & & & \\
\hline
\end{tabular}

${ }^{*} p<.05 ;{ }^{* *} p<.01 ;{ }^{* * *} p<.001$. All significance tests are two-tailed tests. All models include controls for age, SES, and race. 


\section{The Moderating Effect of Morality}

In the final series of analyses, I examined first the gender difference in both morality and religiosity, the effects of morality and religiosity on deviance, the effects of morality and religiosity on deviance controlling for deviant association. and the interaction effects between morality and deviant association and between religiosity and deviant association on deviance. Finally, in the last model, I took into account the gender difference in morality as a moderating effect explaining the gendered effect of deviant association on deviance found in Table 3.

First, I examined the gender difference in morality using the Ordinary Least Squares regression, and morality and religiosity were regressed separately on gender and three control variables (results not shown). As expected, the result showed that males hold a significantly weaker morality than females $(\beta=-0.256, p<.001)$; on the other hand, contrary to our expectation, there was no significant gender difference in religiosity.

Then, I regressed deviance on gender, three control variables, and both morality and religiosity (results not shown) and then added deviant association to the model (see Model 1 for the combined sample in Table 4). I first included all association measures that were shown significant in Table 3, then any insignificant association measures were taken out of the model. After eliminating insignificant association measures. the final model shown in Model 1 includes only the matching deviant association measure for all four types of deviance.

When deviant association was not controlled, overall, morality had a significant negative effect on all four types of deviance, whereas religiosity had a significant negative effect on only intemperance and drug deviance. The differences in how morality and religiosity relate to deviance overall signify that these two morality measures are not necessarily identical nor reflect a single morality concept. After drug association was entered into the equation (shown in Model 1), for the combined sample in Table 4, however, morality no longer showed a significantly effect on drug deviance, while religiosity remained significant in this equation. Model 1 overall shows that morality and religiosity combined with deviant association could not explain the gender gap in illegal or serious deviance, as the effect of gender on these two types of deviance remained significant.

Interestingly, it appears that gender and religiosity operate oppositely of one another on deviance after controlling for deviant association; whereas gender was significantly related to more strongly condemned deviance (illegal and serious deviance), religiosity was significantly related to less strongly condemned deviance (intemperance and drug deviance). The results concerning religiosity's effect on deviance are on par with past studies, which found that religiosity plays a much more important role in preventing behaviors that concern pleasure and that are less strongly condemned (Burkett and White 1974). Despite the importance of both morality and religiosity in reducing deviance, however, the effect of deviant association trumped those of morality and religiosity on all four types of deviance.

Next, I regressed deviance on gender, three control variables, deviant association, both morality and religiosity, and interaction terms between gender and morality and gender and religiosity (see Model 2 for the combined sample in Table 4). Each equation was re-analyzed when one of the interaction terms was insignificant, and only significant interaction terms were included in the final model that is reported in Model 2. Overall, all significant interaction terms indicated that both morality and religiosity prevented the effect of deviant association on deviance, but the preventive effect varied depending on the type of deviance. Overall, religiosity significantly 
TABLE 4

Multivariate General Linear Model Regressing Deviance on Four Control Variables, Deviant Association, Morality, Religiosity, and Interaction Terms Between Morality and Each of the Deviant Association Scales and Religiosity and Each of the Deviant Association Scales for the Combined Sample and Males and Females Separately

\begin{tabular}{|c|c|c|c|c|c|c|c|c|c|c|c|c|c|c|c|c|}
\hline \multirow[b]{3}{*}{ Type of deviance } & \multicolumn{8}{|c|}{ Combined } & & & & & & & & \\
\hline & \multicolumn{4}{|c|}{$\begin{array}{c}\text { Model } 1 \\
(N=502)\end{array}$} & \multicolumn{4}{|c|}{$\begin{array}{c}\text { Model } 2 \\
(N=502)\end{array}$} & \multicolumn{4}{|c|}{$\begin{array}{c}\text { Males } \\
(n=214)\end{array}$} & \multicolumn{4}{|c|}{$\begin{array}{c}\text { Females } \\
(n=288)\end{array}$} \\
\hline & $B$ & $p$ & $S E$ & $t$ & $B$ & $p$ & $S E$ & $t$ & $B$ & $p$ & $S E$ & $t$ & $B$ & $p$ & $S E$ & $t$ \\
\hline \multicolumn{17}{|l|}{ Intemperance } \\
\hline Intercept & -4.796 & $* *$ & 1.449 & -3.310 & -4.697 & $* *$ & 1.439 & -3.264 & & & & & -4.132 & * & 1.803 & -2.292 \\
\hline Gender $($ Males $=1)$ & 0.214 & & 0.206 & 1.040 & 0.229 & & 0.205 & 1.119 & & & & & & & & \\
\hline Religiosity & -0.274 & $* * *$ & 0.076 & -3.583 & -0.306 & $* * *$ & 0.077 & -3.986 & & & & & -0.227 & $*$ & 0.097 & -2.338 \\
\hline Morality & -0.186 & $* * *$ & 0.036 & -5.168 & -0.184 & $* * *$ & 0.036 & -5.143 & & & & & -0.134 & $* *$ & 0.047 & -2.845 \\
\hline Intemperance Association & 0.540 & $* * *$ & 0.034 & 16.025 & 0.656 & $* * *$ & 0.052 & 12.498 & & & & & 0.722 & $* * *$ & 0.069 & 10.477 \\
\hline Religiosity $\times$ Intemperance Association & & & & & -0.061 & $* *$ & 0.021 & -2.868 & & & & & -0.070 & * & 0.028 & -2.518 \\
\hline Adj. $R^{2}$ & 0.518 & & & & 0.525 & & & & & & & & 0.522 & & & \\
\hline \multicolumn{17}{|l|}{ Illegal } \\
\hline Intercept & -1.541 & & 1.346 & -1.145 & -1.386 & & 1.310 & -1.058 & -3.125 & & 2.484 & -1.258 & 0.088 & & 1.363 & 0.065 \\
\hline Gender $($ Males $=1)$ & 0.644 & $* *$ & 0.199 & 3.237 & 0.690 & $* * *$ & 0.194 & 3.562 & & & & & & & & \\
\hline Religiosity & -0.038 & & 0.069 & -0.554 & -0.054 & & 0.067 & -0.800 & -0.038 & & 0.130 & -0.293 & -0.084 & & 0.067 & -1.253 \\
\hline Morality & -0.149 & $* * *$ & 0.033 & -4.492 & -0.148 & $* * *$ & 0.032 & -4.574 & -0.216 & $* * *$ & 0.059 & -3.682 & -0.068 & & 0.037 & -1.855 \\
\hline Illegal Association & 0.395 & $* * *$ & 0.039 & 10.167 & 0.323 & $* * *$ & 0.040 & 8.050 & 0.254 & $* * *$ & 0.070 & 3.620 & 0.409 & $* * *$ & 0.045 & 9.183 \\
\hline Morality $\times$ Illegal Association & & & & & -0.056 & $* * *$ & 0.010 & -5.374 & -0.060 & $* *$ & 0.018 & -3.407 & -0.046 & $* *$ & 0.015 & -3.126 \\
\hline Adj. $R^{2}$ & 0.327 & & & & 0.363 & & & & 0.291 & & & & 0.298 & & & \\
\hline \multicolumn{17}{|l|}{ Drug } \\
\hline Intercept & -5.984 & $* * *$ & 1.296 & -4.618 & -5.775 & $* * *$ & 1.222 & -4.727 & -9.755 & $* * *$ & 2.201 & -4.433 & -1.987 & & 1.363 & -1.458 \\
\hline Gender $($ Males $=1)$ & 0.104 & & 0.185 & 0.566 & 0.093 & & 0.174 & 0.533 & & & & & & & & \\
\hline Religiosity & -0.194 & $* *$ & 0.068 & -2.862 & -0.276 & $* * *$ & 0.065 & -4.257 & -0.329 & $* *$ & 0.119 & -2.766 & -0.222 & $* *$ & 0.072 & -3.073 \\
\hline Morality & -0.058 & & 0.032 & -1.806 & -0.051 & & 0.031 & -1.662 & -0.071 & & 0.051 & -1.385 & -0.070 & & 0.036 & -1.941 \\
\hline Drug Association & 0.536 & $* * *$ & 0.038 & 14.159 & 0.742 & $* * *$ & 0.057 & 13.037 & 0.844 & $* * *$ & 0.080 & 10.615 & 0.628 & $* * *$ & 0.068 & 9.222 \\
\hline Religiosity $\times$ Drug Association & & & & & -0.163 & $* * *$ & 0.027 & -6.022 & -0.198 & $* * *$ & 0.043 & -4.663 & -0.121 & $* * *$ & 0.031 & -3.846 \\
\hline Morality $\times$ Drug Association & & & & & -0.023 & $*$ & 0.011 & -2.168 & & & & & -0.048 & $* *$ & 0.015 & -3.196 \\
\hline Adj. $R^{2}$ & 0.412 & & & & 0.479 & & & & 0.507 & & & & 0.421 & & & \\
\hline
\end{tabular}


TABLE 4

(Continued)

\begin{tabular}{|c|c|c|c|c|c|c|c|c|c|c|c|c|c|c|c|c|}
\hline \multirow[b]{3}{*}{ Type of deviance } & \multicolumn{8}{|c|}{ Combined } & & & & & & & & \\
\hline & \multicolumn{4}{|c|}{$\begin{array}{c}\text { Model } 1 \\
(N=502)\end{array}$} & \multicolumn{4}{|c|}{$\begin{array}{c}\text { Model } 2 \\
(N=502)\end{array}$} & \multicolumn{4}{|c|}{$\begin{array}{c}\text { Males } \\
(n=214)\end{array}$} & \multicolumn{4}{|c|}{$\begin{array}{c}\text { Females } \\
(n=288)\end{array}$} \\
\hline & $B$ & $p$ & $S E$ & $t$ & $B$ & $p$ & $S E$ & $t$ & $B$ & $p$ & $S E$ & $t$ & $B$ & $p$ & $S E$ & $t$ \\
\hline \multicolumn{17}{|l|}{ Serious } \\
\hline Intercept & -4.051 & $* *$ & 1.569 & -2.582 & -4.183 & $* *$ & 1.561 & -2.679 & & & & & & & & \\
\hline Gender $($ Males $=1)$ & 1.142 & $* * *$ & 0.230 & 4.974 & 1.152 & $* * *$ & 0.228 & 5.044 & & & & & & & & \\
\hline Religiosity & 0.069 & & 0.080 & 0.862 & 0.067 & & 0.080 & 0.845 & & & & & & & & \\
\hline Morality & -0.163 & $* * *$ & 0.039 & -4.226 & -0.164 & $* * *$ & 0.038 & -4.278 & & & & & & & & \\
\hline Serious Association & 0.480 & $* * *$ & 0.033 & 14.325 & 0.464 & $* * *$ & 0.034 & 13.702 & & & & & & & & \\
\hline Morality $\times$ Serious Association & & & & & -0.026 & $*$ & 0.010 & -2.580 & & & & & & & & \\
\hline Adj. $R^{2}$ & 0.459 & & & & 0.465 & & & & & & & & & & & \\
\hline
\end{tabular}

${ }^{*} p<.05 ;{ }^{* *} p<.01 ;{ }^{* * *} p<.001$. All significance tests are two-tailed tests. All models include controls for age, SES, and race. 
prevented the effects of intemperance and drug association on corresponding deviant behaviors, while morality significantly prevented the effects of illegal, drug, and serious association on corresponding deviant behaviors. The findings shown in Model 2 overall mirror those shown in Model 1, such that religiosity overall had a stronger preventive effect on less strongly condemned deviance (intemperance and drug deviance), while morality, much like gender, overall had a stronger preventive effect on more strongly condemned deviance (illegal and serious deviance).

Finally, I examined whether morality moderates the effect of deviant association on deviance and also explains the gendered effect of deviant association on deviance reported in Table 3. To examine this, I conducted an analysis separately for males and females and regressed deviance on three control variables, deviant association, morality, religiosity, and the interaction terms between morality and deviant association as well as between religiosity and deviant association (see the models for males and females in Table 4). Table 4 reports for both males and females only those equations with at least one significant interaction term. The results overall indicate that morality and religiosity moderate the effect of deviant association on deviance for both genders; however, how the two morality measures moderate the effect of deviant association depends on the type of deviance and also on gender. Furthermore, morality and religiosity overall failed to explain fully the gendered effect of deviant association on drug and serious deviance reported earlier.

Table 4 shows that religiosity significantly reduced the effect of intemperance association on intemperance deviance only for females. On the other hand, morality significantly reduced the effect of illegal association and religiosity of drug association on the corresponding deviance for both genders. Finally, morality significantly reduced the effect of drug association on drug deviance only for females. There was, however, no significant moderating effect of morality with respect to intemperance association or of both morality and religiosity with respect to serious association on their respective deviant behaviors. Although the results are not shown, males and females were combined and a three-way interaction term (e.g., gender, morality, and illegal association) was entered in the equation to examine the gender difference in the moderating effects of religiosity and morality. The only three-way interaction term that was significant was the one with gender, religiosity, and intemperance association in the equation with intemperance deviance as the dependent variable. This indicates that religiosity significantly more strongly reduced the effect of intemperance association on intemperance deviance for females compared to males.

Our results in Table 4 overall indicated that although morality and religiosity did moderate the effect of deviant association on deviance for some types of deviance, the moderating effect did not differ by gender for the most part with one exception. The one exception is the significant gender difference in the moderating effect of religiosity found with respect to intemperance association. Our results, therefore, indicate that morality and religiosity overall fail to explain the gendered effect of deviant association found on drug deviance or serious deviance (see Table 3 ).

\section{DISCUSSION}

This study replicated Mears et al. (1998) and Piquero et al. (2005) but went further by taking into account the dimensionality of deviance. Using four scales measuring different types of deviant behaviors that were created based on 15 deviant behaviors. I examined how the type of deviance conditions the expected gendered effect of deviant association on deviance. The literature 
reviewed and the results of this study generated five major implications. First, the gender gap was found in both deviance and deviant association for all four types of deviant behaviors. Confirming the past research, moreover, the gender gap in more strongly condemned deviance/deviant association was wider than the gender gap in less strongly condemned deviance/deviant association. Second. deviant association explained the gender gap in less strongly condemned deviance but not in more strongly condemned deviance. Third, the matching deviant association scale explained deviance better than did un-matching deviant association scales. Fourth, the gendered effect of deviant association was found on intemperance, drug, and serious deviant association on their respective deviance scales, but the direction of the gendered effect varied depending on the type of deviance and gender. Fifth, both morality and religiosity were found to moderate the effect of deviant association on deviance, but the moderating effects for the most part did not differ across gender, and morality and religiosity overall failed to explain the gendered effect of deviant association on deviance or the overall gender gap in more strongly condemned deviant behaviors. I now discuss each of these five points in detail in the following.

First, males are more deviant than females for all four types of deviant behaviors, and consistent with the past research, the gender gap in more strongly condemned deviance (illegal and serious deviance) was significantly wider than the gender gap in less strongly condemned deviance (intemperance and drug deviance). The results for deviant association mirrored those for deviance, including the significantly wider gender gap found in illegal and serious association than in intemperance and drug association.

Second, the similarity in the effect of gender on deviance and that on deviant association led to the prediction that the gender gap in deviant association could explain the gender gap in deviance. Indeed. deviant association explained the gender gap in less strongly condemned deviance but failed to explain the gender gap in more strongly condemned deviance. Overall the results indicated that males are more likely than females to engage in both intemperance and drug deviance because males are more likely than females to associate with friends who engage in intemperance and drug deviance, respectively. The inability of deviant association to explain away the gender gap in more strongly condemned deviance suggests the possibility that the more strongly condemned the deviance, the more important other factors besides deviant association become in explaining the gender gap. As previous studies (e.g. Mears et al. 1998; Piquero et al. 2005) proposed, other factors might include morality that could affect deviance more or less strongly depending on the level of seriousness of the deviant behaviors.

Interestingly, religiosity operated oppositely of gender on its effect on deviance when controlling for deviant association. While the effect of religiosity remained significant on intemperance and drug deviance, its effect disappeared on illegal and serious deviance once deviant association was controlled. The results are consistent with the past studies (e.g., Burkett and White 1974), which found that religiosity plays a much more important role in preventing behaviors that concern pleasure and that are less strongly condemned than behaviors that are morally unambiguous and more strongly condemned by society. It is consistent with Durkheim's (1912) argument that when there are clearly specified laws against behaviors, religion is unnecessary to regulate the behaviors (see also Burkett and Ward 1993). The insignificance of religiosity on illegal and serious deviance, once controlling for deviant association, was explained by the lower likelihood of those who are religious to associate with friends who engaged in illegal or serious deviance. While religiosity remained important in preventing both intemperance and drug deviance, controlling for deviant association, gender remained important in explaining illegal and serious 
deviance, controlling for deviant association. The comparison of the effects of religiosity and gender on deviance after controlling for deviant association, overall, suggests that how well a theory explains deviance or group variations in deviance might depend on the type of deviance, and thus, it is important to take into account the dimensionality of deviance when applying a theory. Furthermore, the similarity in the effect of morality and that of gender on deviance when controlling for deviant association suggests that gender as a construct may reflect more than the mere groupings by sex but an overarching behavior-regulating force, like morality, such as gender norms. Our results indicate that both morality and gender play much more important roles in regulating strongly condemned behaviors like illegal and serious deviance.

Third, when it comes to deviant association, the matching deviant association scale explained the deviance better than did un-matching deviant association scales. This is understandable given social learning theory's emphasis on the process of learning of a certain behavior within the differential association, which involves learning of definitions, reinforcements, imitations, and so on (Akers and Sellers 2012). Although the concept of "differential association" is important, the likelihood that one engages in a deviant behavior is affected not just by the deviant association but more specifically by the learning of favorable definitions about the deviant behavior, the reinforcement for the deviant behavior one receives from others, and the imitation of the deviant behavior. The learning of a certain deviant behavior is more likely to occur when one associates with friends who engage in the behavior than other behaviors.

Fourth, the gendered effect of deviant association was found on intemperance, drug, and serious deviance but not on illegal deviance. Confirming Mears et al. (1998) and Piquero et al. (2005), our results overall indicated that drug and serious association affected males' engagement in corresponding deviance more strongly than females' engagement. Additionally, our results also indicated that how gender conditions the effect of deviant association on deviance was partially dependent on the type of deviance. The findings offer a possible explanation why past studies found mixed gendered effect of deviant association on deviance because studies varied in terms of the type of deviant behaviors they examined. Specifically, the results show that drug association had a significantly stronger positive effect on intemperance deviance among females compared to its insignificant effect among males on the same deviant behaviors.

Fifth, both morality and religiosity were found to moderate the effect of deviant association on deviance, but the moderating effect did not differ by gender, except for one twist, and thus, morality and religiosity overall failed to explain the gendered effect of deviant association on both drug and serious deviance. Table 4 shows that morality significantly reduced the effect of illegal and drug association on corresponding deviance, but the moderating effects were found equally among both genders. Similarly, though religiosity significantly reduced the effect of $d r u g$ association on drug deviance, the moderating effect was found equally among both genders. Finally, though the moderating effect of religiosity on the relationship between intemperance association and deviance was found just for females, intemperance association did not show any gendered effect, as shown in Table 3. Finally, though females have stronger moral beliefs than males, morality along with deviant association and religiosity overall failed to explain the gender gap in illegal and serious deviance.

There are several limitations of this study that can generate future recommendations that I now discuss in detail. First, the findings might have limited generalizability because the study used a non-random sample of college students from a university. Our main objective was, however, not 
the predictions but rather an examination of the gender difference in how theoretical variables explain deviance. The use of a less deviant college-student sample, thus, makes this study a more conservative test of the effects of theoretical variables on deviance due to the sample's low variability on both deviance and deviant association. Nonetheless, a suggestion for future research is the use of a more representative sample of a population of youth. Additionally, though this study utilized a list of general deviant behaviors popularly used in delinquency studies (e.g., Elliot, Huizinga, and Ageton 1985), more studies are needed that target serious deviant acts among delinquents. A high variability in both less serious and more serious deviant behaviors among delinquents might provide a more adequate comparison of the two types of deviant behaviors in terms of how they relate to theoretical variables, like deviant association. Second, one of the important issues with respect to social learning theory is the temporal order between deviant association and deviance. In this study, I made an assumption theoretically concerning the temporal order of variables. Our data, however, used measures of deviance and deviant association based on respondents' answers that referred to the same time period (e.g., past 12 months), and this poses a limitation in explicating the causal model across gender. Better research, therefore, would employ the longitudinal design where the data collection of the independent variable (deviant association) occurs prior to the data collection of the dependent variable (deviance). Third. the findings would be enhanced had we included a scale that measured deviant behaviors that were more common among females. A suggestion for future research, therefore, is to include at least three types of deviance: one more common among males, another more common among females, and another equally common among males and females. It is also important for future studies to consider theoretically classifying and constructing different types of deviance scales, such as the one offered by Broidy and Agnew (1997), rather than using a post-facto classification based on the factor analysis, as was the case in our study. One of the limitations with creating deviance scales based on factor analysis results is the possibility that scales do not show clear deviance types, and thus, overlap in terms of the type of deviance, as seen in this study between serious and illegal deviance scales. It is also important for future studies to examine numerous different kinds of deviant behaviors, identify if there are gender differences, and examine the patterns of such gender differences. Fourth, the data used in this study did not ask the gender of deviant friends. Because past studies consistently found differences in the effect of deviant association on deviance based on the gender of the deviant friends, especially for females (e.g. Giordano 1978), it is important to consider the gender of deviant friends. I do not believe, however, that the lack of knowledge of the gender of deviant friends has undermined the overall findings of the study, namely the importance of taking into account the dimensionality of deviance when examining a gendered effect of the theoretical variables on deviance. In order to understand more fully the applicability of social learning theory as well as the gendered effect of deviant association on deviance, however, an in-depth examination of the quality and type of peers, including the gender of the peers, is needed. Finally, our study did not specify theoretically or empirically what the constructs such as "gender" and "religiosity" exactly measure. Besides signifying two different groups, the construct "gender," for instance, could be capturing concepts such as gender norms, gender expectations, gender roles, and so on. It is, therefore. important for future comparative, empirical studies to include measures that would explain group characteristics overall that could then affect deviance and account for the gender gap in deviance. 


\section{ACKNOWLEDGMENTS}

I am most grateful to Dr. Susan F. Sharp and Dr. Harold G. Grasmick for their contributions to collecting the data and their invaluable input into the article.

\section{FUNDING}

Funding for the survey reported was provided by the College of Arts and Sciences, University of Oklahoma (Susan F. Sharp, PI).

\section{REFERENCES}

Agnew, Robert. 2006. Pressured into Crime: An Overview of General Strain Theory. Los Angeles, CA: Roxbury Publishing Company.

Akers, Ronald L. and Gary F. Jensen. 2008. "The Empirical Status of Social Learning Theory of Crime and Deviance: The Past, Present, and Future." Pp. 37-76 in Taking Stock: The status of Criminological Theory: Advances in Criminological Theory Volume 15, edited by F. T. Cullen, J. P. Wright, and K. R. Blevins. New Brunswick, NJ: Transaction Publishers.

Akers, Ronald L. and Christine S. Sellers. 2012. Criminological Theories: Introduction, Evaluation, and Application, 6th edition. New York: Oxford University Press.

Alarid, Leanne Fietal, Velmer S. Burton, Jr., and Francis T. Cullen. 2000. "Gender and Crime Among Felony Offenders: Assessing the Generality of Social Control and Differential Association Theories." Journal of Research in Crime and Delinquency 37(2): 171-199.

Allison, Pauld David. 1999. Multiple Regression: A Primer. Thousand Oaks, CA: Pine Forge Press.

Batson, C. Daniel and W. Larry Ventis. 1982. The Religious Experience. New York: Oxford University Press.

Belknap, Joanne and Kristi Holdinger. 2006. "The Gendered Nature of Risk Factors for Delinquency." Feminist Criminology 1(1):48-71.

Bensen, Peter L., Michael J. Donahue, and Joseph A. Erickson. 1989. "Adolescence and Religion: A Review of the Literature from 1970-1986." Research in the Social Scientific Study of Religion 1:153-181.

Beutel, Ann and Margaret Mooney Marini. 1995. "Gender and Values." American Sociological Review 60:436-448.

Bottcher, Jean. 2001. "Social Practices of Gender: How Gender Relates to Delinquency in the Everyday Lives of HighRisk Youths.” Criminology 39(4):893-931.

Broidy, Lisa and Robert Agnew. 1997. "Gender and Crime: A General Strain Theory Perspective." Joumal of Research in Crime and Delinquency 34(3):275-306.

Burgess, Robert and Ronald Akers. 1966. "A Differential Association-Reinforcement Theory of Criminal Behavior." Social Problems 14(2):128-147.

Burkett, Steven R. and David A. Ward. 1993. “A Note on Perceptual Deterrence, Religiously Based Moral Condemnation, and Social Control." Criminology 31(1):119-134.

Burkett, Steven R and Mervin White. 1974. "Hellfire and Delinquency: Another Look." Journal for the Scientific Study of Religion 13(4):455-462.

Caplow, Theodore, Howard M. Bahr, and Bruce A. Chadwick. 1983. All Faithful People: Change and Continuity in Middletown's Religion. Minneapolis, MN: University of Minnesota Press.

Chesney-Lind, Meda. 1989. "Girl's Crime and Women's Place: Toward a Feminist Model of Female Delinquency." Crime and Delinquency 35:5-29.

—_ 2006. "Patriarchy, Crime, and Justice: Feminist Criminology in an Era of Backlash." Feminist Criminology $1(1): 6-26$.

Chesney-Lind, Meda and Lisa Pasko. 2013. The Female Offender: Girls, Women, and Crime, 3rd Edition. Los Angeles, CA: Sage.

Chesney-Lind, Meda and Randall G. Shelden. 2004. Girls, Delinquency. And Juvenile Justice (3rd Ed.). Belmont, CA: Thompson/Wadsworth. 
Cornwall, Marie. 1989. “The Influence of Three Agents of Religious Socialization: Family, Church, and Peers." Pp. 207-231 in The Religion and Family Connection: Social Science Perspectives, edited by D. L. Tomas. Provo, UT: Religious Studies Center, Brigham Young University.

Crick, Nicki R., Maureen. A. Bigbee, and Cynthia Howes. 1996. "Gender Differences in Children's Normative beliefs about Aggression: How Do I Hurt Thee? Let me Count the Ways." Child Development 67:1003-1014.

Crick, Nicki R. and Jennifer Grotpeter. 1995. "Relational Aggression, Gender, and Social-Psychological Adjustment." Child Development 66:710-722.

Daigle, Leah E., Francis T. Cullen, and John Paul Wright. 2007. "Gender Differences in the Predictors of Juvenile Delinquency: Assessing the Generality-Specificity Debate." Youth Violence and Juvenile Justice 5(3):254-286.

Daly, Kathleen. 1994. Gender, Crime, and Punishment. New Heaven, CT: Yale University Press.

. 1998. "Gender, Crime, and Criminology." Pp. 85-108 in The Handbook of Crime and Punishment, edited by M. H. Tonry. New York: Oxford University Press.

Daly, Kathleen and Meda Chesney-Lind. 1988. "Feminism and Criminology." Justice Quarterly 5(4):497-538.

Durkheim, Emile. 1912. The Elementary Forms of Religious Life. London: Allen and Unwin Ltd.

Elliot, Delbert S., David Huizinga, and Suzanne S. Ageton. 1985. Explaining Delinquency and Drug Use. Beverly Hills, CA: Sage.

Gilligan, Carol. 1982. In a Different Voice: Psychological Theory and Women's Development. Cambridge, MA: Harvard University Press.

Giordano, Peggy C. 1978. "Guys, Girls, and Gangs: The Changing Social Context of Female Delinquency." Joumal of Criminal Law and Criminology 69(1):126-132.

Gottfredson, Michael R. and Travis Hirschi. 1990. A General Theory of Crime. Stanford, CA: Stanford University Press.

Hagan, John, A. R. Gills, and John Simpson. 1985. "The Class Structure of Gender and Delinquency: Toward a PowerControl Theory of Common Delinquent Behavior." American Journal of Sociology 95:1151-1178.

Hartjen, C. A. and S. Priyadarsini. 2003. "Gender, Peers, and Delinquency: A Study of Boys and Girls in Rural France." Youth and Society $34: 387-414$.

Heidensohn, Frances. 2002. "Gender and Crime." Pp. 491-530 in The Oxford Handbook of Criminology (3rd Ed.), edited by M. Maguire, R. Morgan, and R. Reiner. New York: Oxford University Press.

Heimer, Karen and Stacy De Coster. 1999. "The Gendering of Violent Delinquency." Criminology 37(2):277-318.

Hindelang, Michael. 1979. "Sex Differences in Criminal Activity." Social Problems 27:143-156.

Hindelang, Michael, Travis Hirschi, and Joesh G. Weis. 1979. "Correlates of Delinquency: The Illusion of Discrepancy between Self-Report and Official Measures." American Sociological Review 44:995-1014. 1981. Measuring Delinquency. Beverly Hills, CA: Sage Publication.

Jensen Gary F. 2003. "Gender Variation in Delinquency: Self-Image, Beliefs and Peers as Mediating Mechanisms." Pp. 151-177 in Advances in Criminological Theory: A Guide for the New Century: Social Learning Theory and the Explanation of Crime, edited by R. L. Akers and G. F. Jensen. New Brunswick, NJ: Transaction.

Johnson, Richard E. 1979. Juvenile Delinquency and Its Origins: An Integrated Theoretical Approach. Cambridge, UK: Cambridge University Press.

Liu, Xiaoru and Howard B. Kaplan. 1999. "Explaining the Gender Difference in Adolescent Delinquent Behavior: A Longitudinal Test of Mediating Mechanisms." Criminology 37(1):195-215.

Lowe, Nathan C., David C. May, and Preston Elrod. 2008. "Theoretical Predictors of Delinquency among Public School Students in a Mid-Southern State: The Roles of Context and Gender." Youth Violence and Juvenile Justice 6(4):343-362.

Mears, Daniel P., Matthew Ploeger, and Mark Warr. 1998. "Explaining the Gender Gap in Delinquency: Peer Influence and Moral Evaluations of Behavior." Journal of Research in Crime and Delinquency 35:251-266.

Messerschmidt, James W. 1993. Masculinities and Crime: Critique and Reconceptualization. Lanham, MD: Rowman and Littlefield Publishers.

Morash, Merry. 1986. “Gender, Peer Group Experiences, and Seriousness of Delinquency.” Journal of Research in Crime and Delinquency 23:46-67.

Naffine, Ngaire. 1996. Feminism and Criminology. Philadelphia, PA: Temple University Press.

O'Brien, Robert M. 2007. "A Caution Regarding Rules of Thumb for Variance Inflation Factors." Quality and Quantity 41:673-690.

Piquero, Nicole Leeper, A. R.Gover, J. M. MacDonald, and Alex R. Piquero. 2005. "The Influence of Delinquent Peers on Delinquency: Does Gender Matter?" Youth and Society 36:251-275. 
Preston, Pamela. 2006. "Marijuana Use as a Coping Response to Psychological Strain: Racial, Ethnic, and Gender Differences Among Young Adults." Deviant Behavior 27(4):397-421.

Schwartz, Jennifer, Darrell Steffensmeier, Hua Zhong, and Jeff Ackerman. 2009. "Trends in the Gender Gap in Violence: Reevaluating NCVS and Other Evidence." Criminology 47(2):401-425.

Sharp, Susan F., Dennis Brewster, and Sharon R. Love. 2005. "Disentangling Strain, Personal Attributes, Affective Response, and Deviance: A Gendered Analysis." Deviant Behavior 26:133-157.

Sharp, Susan F. and Kristen Hefley. 2007. "This is a Man's World .. or Least That's How It Looks in the Journals." Critical Criminology 15(1):3-18.

Sheley, Joseph F. 2000. Criminology. Belmont, CA: Wadsworth/Thomson Learning.

Simons, Ronald L., Martin G. Miller, and Stephen M. Aigner. 1980. "Contemporary Theories of Deviance and Female Delinquency: An Empirical Test." Journal of Research in Crime and Delinquency 17:42-57.

Smith, Douglas. 1979. "Sex and Deviance: An Assessment of Major Sociological Variables." Sociological Quarterly 20:183-195.

Smith, Douglas and Raymond Paternoster. 1987. "The Gender Gap in Theories of Deviance: Issues and Evidence." Journal of Research on Crime and Delinquency 24:140-172.

Stark, Rodney and William Bainbridge. 1985. The Future of Religions. Berkeley: University of California Press.

Steffensmeier, Darrel1. 2000. "Gender, Structural Disadvantage, and Urban Crime: Do Macrosical Variables also Explain Female Offending Rates?" Criminology 38:403-438.

Steffensmeier, Darrell and Emilie Allen. 1988. "Sex Disparities in Arrests by Residence, Race, and Age: An Assessment of the Gender Convergence/Crime Hypothesis." Justice Quarterly 5:53-80.

—_. 1995. "Gender, Age, and Crime." Pp. 83-113 in Handbook of Contemporary Criminology (2nd Ed.), edited by J. F. Sheley. Belmont, CA: Wadsworth.

_ 1996. "Gender and Crime: Toward a Gendered Theory of Female Offending." Annual Review of Sociology 22:459-487.

Steffensmeier, Darrell, Emilie Allan, and Cathy Streifel. 1989. "Development and Female Crime: A Cross-National Test of Alternative Explanations." Social Forces 68:262-283.

Steffensmeier, Darrell and Dana Haynie. 2000. "Structural Sources of Urban Violence in the United States: A Macrosocial Gender-Disaggregated Analysis of Adult and Juvenile Homicide Offending Rates." Homicide Studies 4(2): $107-134$.

Steffensmeier, Darrell and Cathy Streifel. 1991. “Age, Gender, and Crime Across Three Historical Periods: 1935, 1960, 1985." Social Forces 69(3):869-894.

Sutherland, Edwin H. 1939. Principles of Criminology, 3rd Ed. Philadelphia: Lippincott.

Sutherland, Edwin H., Donald R. Cressey, and David F. Lukenbill. 1992. Principles of Criminology. Lanham, MD: Rowman and Littlefield Publishers.

Tittle, Charles R. and Raymond Paternoster. 2000. Social Deviance and Crime: An Organizational and Theoretical Approach. Los Angeles, CA: Roxbury Publishing Company.

Warr, Mark. 2002. Companions in Crime: The Social Aspects of Criminal Conduct. Cambridge, UK: Cambridge University Press.

Weerman, Frank W. and Machteld Hoeve. 2012. "Peers and Delinquency among Girls and Boys: Are Sex Differences in Delinquency Explained by Peer Factors?" European Joumal of Criminology 9(3):228-244.

Wilson, James Q. and William Hernstein. 1985. Crime and Human Nature. New York: Simon and Schuster.

Zahn, Margaret A. Robert Agnew, Diana Fishbein, Shari Miller, Donna-Marie Winn, Gayle Dakoff, Candace Kruttschnitt, Peggy Giordano, Denise C. Gottfredson, Allison A. Payne, Barry C. Feld, and Meda Chesney-Lind. 2010. Causes and Correlates of Girls' Delinquency. Rockville, MD: Office of Juvenile Justice and Delinquency Prevention, U.S. Department of Justice.

Zimmerman, Gregory M. and Steven F. Messner. 2010. "Neighborhood Context and Gender Gap in Adolescent Violence." American Sociological Review 75(6):958-980.

MIYUKI FUKUSHIMA TEDOR is an Assistant Professor in the Department of Sociology and Criminology at Cleveland State University. Her research focuses on theory testing of crime; gender and crime; juvenile delinquency; and cross-national studies of crime, particularly those between Japan and the United States. 
Copyright of Deviant Behavior is the property of Routledge and its content may not be copied or emailed to multiple sites or posted to a listserv without the copyright holder's express

written permission. However, users may print, download, or email articles for individual use. 